\title{
Editorial for the Special Issue "Mineral Textural and Compositional Variations as a Tool for Understanding Magmatic Processes"
}

\author{
Silvio Mollo ${ }^{1,2, *(\mathbb{D}}$, Flavio Di Stefano ${ }^{2}$ and Francesca Forni ${ }^{3}$ \\ 1 Department of Earth Sciences, Sapienza-Università di Roma, 00185 Rome, Italy \\ 2 National Institute of Geophysics and Volcanology (INGV), 00143 Rome, Italy; flavio.distefano@ingv.it \\ 3 Asian School of the Environment, Nanyang Technological University, 637459 Singapore, Singapore; \\ fforni@ntu.edu.sg \\ * Correspondence: silvio.mollo@uniroma1.it
}

Citation: Mollo, S.; Di Stefano, F.; Forni, F. Editorial for the Special Issue "Mineral Textural and Compositional Variations as a Tool for Understanding Magmatic Processes". Minerals 2021, 11, 102. https://doi.org/10.3390/ $\min 11020102$

Received: 5 January 2021

Accepted: 19 January 2021

Published: 21 January 2021

Publisher's Note: MDPI stays neutral with regard to jurisdictional claims in published maps and institutional affiliations.

Copyright: (c) 2021 by the authors. Licensee MDPI, Basel, Switzerland. This article is an open access article distributed under the terms and conditions of the Creative Commons Attribution (CC BY) license (https:// creativecommons.org/licenses/by/ $4.0 /)$.
This Special Issue of Minerals collects seven different scientific contributions highlighting how magma chamber processes and eruption dynamics studied either in the laboratory or in nature may ultimately control the evolutionary histories and geochemical complexities of igneous rocks. The main purpose is to report novel results bearing on the most important mechanisms that govern the textural and compositional changes of minerals and their host rocks. Different scenarios and case studies are presented here regarding the polybaric-polythermal solidification of magmas under either closed or open conditions. Results from these scientific contributions have the potential to elucidate those physicochemical parameters which play key roles in crystallizing systems, when degassing, magma mixing, and magma-fluid-crust interaction phenomena take place over different temporal and spatial scales.

Rare-earth element (REE) modeling based on bulk rock analyses of crustal and mantle xenoliths from alkaline lavas and pyroclastic rocks is used to highlight magma-crust interaction processes between MORB oceanic crust and overlying sediments located beneath the Cape Verde oceanic plateau [1]. Clinopyroxene-based thermobarometric calculations indicate crystallization from magmas stored within the oceanic lithospheric mantle. During ascent towards the surface, these magmas encountered overlying sedimentary rocks and, occasionally, incorporated xenoliths, recording variable degrees of crustal contamination [1].

By integrating geochronological (U-Pb and ${ }^{40} \mathrm{Ar} /{ }^{39} \mathrm{Ar}$ ) and isotope ( $\left.\mathrm{Sr}-\mathrm{Nd}-\mathrm{Pb}-\mathrm{Hf}\right)$ data, a geotectonic model is proposed for Mesozoic magmatic rocks from the South China Sea by involving subduction of an early Neo-Tethyan lithospheric domain [2]. The geochronological and geochemical signatures of adakitic granodiorites and $\mathrm{Nb}$-enriched basalts from the Xiaozhenzhu Seamount outline contemporaneous formation of these products during northward subduction of the proto-South China Sea along the SE Asian continental margin in the Early Cretaceous [2]. A singularity analysis (frequency anomalies) is also applied to U-Pb ages of zircons from the Great Xing' an Range to characterize the causative relationship between age abnormality and Pacific Plate subduction [3]. Data interpretation is consistent with independent geological and geochemical constraints, thus emphasizing the importance of singularity analysis for quantitative characterization of the time scales involved in long-term volcanic activity and past tectonic regimes [3].

The Bushveld Complex (South Africa) is one of the largest igneous complexes on Earth and is also a major deposit of economically viable mineralization. The Merensky Unit, within the Bushveld Complex, indicates origin by magma mixing phenomena resulting from multiple replenishment events [4]. The final solidification process is governed by variable degrees of undercooling, with a role also played by crystal compaction and migration of interstitial fluids. In this perspective, the Merensky Unit is not a cyclic 
unit sensu strictu as the product of closed-system fractional crystallization but rather the Bushveld magma chamber was characterized by open-system processes leading to formation of the Merensky Unit [4]. The Zhesang gold deposit (southeastern Yunnan, China) is another important mining area, located in the Dian-Qian-Gui region. Calcite is a common gangue mineral of the Zhesang deposit, and its origin is related to both ore-stage or post-ore-stage processes [5]. REE and C-O isotopic characteristics of calcite suggest that fluids feeding the growth of ore-stage crystals were derived from a mixture of crustal fluids by meteoric water-leaching wall rocks and a small amount of basic magmatic fluids. On the other hand, the formation of post-ore calcite crystals was driven by fluid-rock interaction phenomena between meteoric water and marine carbonates [5].

Mt. Etna (Sicily, Italy) is the largest volcano in Europe and one of the most active and most intensely monitored on Earth. Hydrous crystallization experiments conducted on trachybasaltic compositions document the intriguing role of $\mathrm{H}_{2} \mathrm{O}$ in the differentiation of magmas ascending throughout the entire plumbing system [6]. The crystallization regime at shallow crustal levels suddenly shifts from $\mathrm{H}_{2} \mathrm{O}$-undersaturated to $\mathrm{H}_{2} \mathrm{O}$-saturated conditions due to the impulsive and irregular arrival of volatile-rich magmas from mantle depths. Abundant release of $\mathrm{H}_{2} \mathrm{O}$ leads to upward acceleration of magmas feeding gasdominated, sustained explosive eruptions, as well as to the voluminous gas emissions measured at summit craters and flank vents [6]. Furthermore, kinetically controlled cation redistributions in phenocrysts from sill-like magmatic intrusions at Mt. Etna testify to dynamic crystallization conditions that are principally controlled by degassing-induced undercooling paths [7]. Early formation of clinopyroxene at depth was the main controlling factor for the REE signature of the sill, whereas subsequent $\mathrm{H}_{2} \mathrm{O}$ loss at lower pressures enlarged the stability field of plagioclase, causing trace element enrichments at pre- and syn-eruptive conditions [7].

Conflicts of Interest: The authors declare no conflict of interest.

\section{References}

1. Barker, A.K.; Hansteen, T.H.; Nilsson, D. Unravelling the Crustal Architecture of Cape Verde from the Seamount Xenolith Record. Minerals 2019, 9, 90. [CrossRef]

2. Cai, G.; Wan, Z.; Yao, Y.; Zhong, L.; Zheng, H.; Kapsiotis, A.; Zhang, C. Mesozoic Northward Subduction Along the SE Asian Continental Margin Inferred from Magmatic Records in the South China Sea. Minerals 2019, 9, 598. [CrossRef]

3. Zhu, P.; Cheng, Q. Singularity Analysis of Volcanic Ages and Implications for Tectonic Setting in the Mesozoic, Great Xing'an Range, Northeast China. Minerals 2019, 9, 419. [CrossRef]

4. Hunt, E.J.; Latypov, R.; Horváth, P. The Merensky Cyclic Unit, Bushveld Complex, South Africa: Reality or Myth? Minerals 2018, 8, 144. [CrossRef]

5. Wang, J.; Chang, J.; Li, C.; Han, Z.; Wang, T.; Han, H. Significance of Calcite Trace Elements Contents and C-O Isotopic Compositions for Ore-Forming Fluids and Gold Prospecting in the Zhesang Carlin-Like Gold Deposit of Southeastern Yunnan, China. Minerals 2020, 10, 338. [CrossRef]

6. Perinelli, C.; Mollo, S.; Gaeta, M.; De Cristofaro, S.P.; Palladino, D.M.; Scarlato, P. Impulsive Supply of Volatile-Rich Magmas in the Shallow Plumbing System of Mt. Etna Volcano. Minerals 2018, 8, 482. [CrossRef]

7. Nazzari, M.; Di Stefano, F.; Mollo, S.; Scarlato, P.; Tecchiato, V.; Ellis, B.; Bachmann, O.; Ferlito, C. Modeling the Crystallization and Emplacement Conditions of a Basaltic Trachyandesitic Sill at Mt. Etna Volcano. Minerals 2019, 9, 126. [CrossRef] 